\title{
Partnering With Industry Via Your Advisory Board
}

\author{
Daniel Davis \\ University of Hartford, ddavis@hartford.edu
}

\begin{abstract}
Many schools and programs have advisory boards that function as little more than a fundraising pool or an audience for the reading of the annual report. Ideally, an advisory board should team with the school to drive the strategic direction while providing advice on various important issues. Having the right group of people on the board is a key factor in determining how effective it will be. But, who are the "right" people? And, how should they be organized? According to many academic leaders, the board should be made up of a small, select group of people with a variety of experiences. This variety of people and experience makes the meetings much more productive and the board much more effective. Finding and attracting the right outside advisors is not as easy as it seems. Regardless of who is on your board, it is important that they can be relied upon for good advice and direction.
\end{abstract}

Index Terms - advisory board, teaming, industry

\section{ADVISORY BOARD FUNDAMENTALS}

Many university programs are now beginning to discover that an advisory board can serve as a valuable complement to the program's leadership team. In fact, in today's increasingly complex and competitive world, the proliferation of advisory boards is helping university programs develop specific plans with clear and effective strategies in order to deliver a quality education.

The term "advisory board" is best defined as: a group of executives, professionals, educators and/or students appointed by the university to provide guidance and support on issues critical to the organization it represents. A board of advisors is a working, as opposed to an honorary, body. A board should offer guidance versus governance, and deliver great insight minus legal liability and statutory responsibility. [1]

An advisory Board is not the same as a:

- Board of directors - has fiduciary responsibilities to the university and its shareholders while maintaining organizational control over the President.

- User group - has students or industrial firms organized and administered to provide input regarding tactical contribution on specific educational issues (found heavily in the IT sector).
- Focus group - has individuals with a specific demographic mix brought into the university to evaluate or discuss a specific topic.

Types of Advisory Boards within the university setting:

- Customer advisory boards - often a group of the most strategic customers (students and firms that typically hire graduates) gathered to offer perspective concerning curriculum, facilities, or industry issues. Unlike user groups, the intent of this type of board is to build relationships with customers or segments that will most directly impact the future of the university program.

- Business-owner advisory boards - often a group of people who evaluate and advise the program leadership on specific aspects of business and provide direction. These outside experts, representing a broad range of business disciplines, act as a sounding board for the strategic plan.

- Industry advisory boards - often a group of influential people assembled to discuss the critical issues facing the industry. These outside experts can be instrumental in bringing an understanding of the industry to the program and aid in the development of leadership. [2]

We have embraced the industrial advisory board approach at the University of Hartford's Department of Architecture. Through many meetings we have been able to bring a better understanding of industry to our students, staff and faculty. We were also able to do the reciprocal and bring a better understanding of our program to local and regional industry leaders. This is mutually beneficial to both parties. As we developed our Master of Architecture program and improved our Architectural Engineering Technology program, the support and involvement of our advisory board was extremely helpful.

\section{WHAT IS AN ADVISORY BOARD?}

Very simply put, advisory groups or advisory committees are a collection of individuals who possess unique understanding, knowledge, and skills which complement the talents of the program's leadership and faculty in order to more effectively, guide the program. The advisory groups are sometimes used to provide a certain type of membership status, for example in Architectural Engineering Technology programs to retired construction related firm leaders or

October 22 - 25, 2008, Saratoga Springs, NY 
major donors. Keep in mind that advisory groups do not have formal authority to govern the organization, that is, they cannot issue directives that must be followed. Rather, advisory groups serve to make recommendations and/or provide key information, materials, and resources to the program's leadership. [3]

We have been fortunate to attract industry leaders to actively participate on the advisory board and help guide our program. Our advisory board has a broad range of personalities, but it is appropriate and balanced. This is a critical aspect of any advisory board. In our situation the board started out as a "working" board where members focused on day-to-day matters as well as the strategic plan, over time it has evolved into a "policy" board where members focus on more strategic matters. We have also found that carefully defining the role of our advisory board has been very helpful.

\section{WHEN SHOULD AN ADVISORY BOARD BE FORMED?}

Some programs consider establishing an advisory group when it is apparent that major, current, or challenging issue are too complex or numerous to be handled by the program's leadership and/or the full-time faculty. Other programs feel it is best if an advisory board is formed to address a need that is usually outside the typical, ongoing roles and responsibilities of the program's leadership and/or full-time faculty. Actually it is best to be equipped with a fully functional advisory board at all times. The advisory board should be a standing (or ongoing) group and not an ad hoc (or one time) group. [4] Enhancing collaboration between higher education and industry is one of the tasks for every engineering technology dean, director and department chair.[5]

Ideally, our department should have formed an advisory board at the onset of the Architectural Engineering Technology Program back in 1992. However, we did not start our board until we began to consider establishing our Master of Architecture program in 2000. Once the board was established, our program, which had been isolated and disconnected from industry, was able to build a better understanding of and relationship to industry. Our board has also been helpful in advising us through a period of great change and growth. When originally established, we had 78 students in our undergraduate program. We currently have 150 undergraduates and 24 graduate students. Our board shares pride in the successful growth of our program.

\section{WHAT ARE THE BOARD MEMBER RESPONSIBILITIES?}

Board members may have specific responsibilities unique to the university program that they serve. The advisory board may also have a variety of responsibilities defined in their bylaws, and in federal and/or state statutes. However, every

978-1-4244-1970-8/08/\$25.00 @2008 IEEE $38^{\text {th }}$ ASEE/IEEE Frontiers in Education Conference board shares a general set of responsibilities that board members should be prepared to assume when they serve. The following may be helpful when the board considers the expectations and responsibilities of its members. [6]

- Attendance

- Participation

- Mission

- Strategic plan

- Board chair

- Organizational planning

- Effectiveness

- Growth and succession planning

We have given our board members responsibilities via subcommittee projects. We have created subcommittees for mission, curriculum, accreditation, and resources. In fact, one of our board members took on the responsibility of improving our architectural library collection with great success. Our collection more than tripled and now exceeds our accreditation requirements. We remind our board that every member shares a set of responsibilities that they should be prepared to assume when they serve, and that their ultimate responsibility is to help improve our program, college and university.

\section{What Makes A SuCCessful BoARd MeMber?}

A board member's success is determined not only by his or her professional skills and experience, but by his or her personality traits and character. In his book "Welcome to the Board," [@1995, Jossey-Bass Inc. Publishers] author Fisher Howe identifies several characteristics of a successful, happy and effective board member:

- They are honest

- They are enthusiastic

- $\quad$ They keep an open mind

- They are team players

- They tackle complex problems with relish

- They take an orderly approach to decision making

- They are competent

- They have a sense of humor

Characteristics that may present a problem include:

- Obsession with a single issue.

- Always taking the "contrarian" view, beyond the point of devil's advocate.

- Expounding on strongly held opinions that are rarely backed up by facts or research.

- "Board hopping" or sitting on many boards, but serving none well. [7]

We have done our best to attract members who meet the above referenced qualifications. However, it is difficult to control the chemistry of any board and we are still working on it. Sometimes informal research is needed, or people

October 22 - 25, 2008, Saratoga Springs, NY 


\section{Session F3A}

invited to serve need to be well known by faculty, to avoid potential clashes of egos that industry leaders often possess (or they would not be leaders). It is important that the advisory board members also work well with the program's staff and full-time faculty.

\section{HOW DO YOU RECRUIT NEW BOARD MEMBERS?}

It is extremely important to keep the perspective that your board deserves highly skilled and involved board members. Do not erode your ambition and believe that you are fortunate to get anyone at all. When you set out to recruit new members, the most important consideration is to know what kinds of skills the board currently needs. Consider the nature of issues and goals currently faced by the program. For example, if you are struggling with fundraising then seek members with strong financial and fundraising skills. It may be useful to do the following:

- Maintain an up-to-date list of potential candidates, including the particular skills they can bring to your program.

- Reference the list of potential candidates to recruit for board membership and ask to meet with them.

- Prospective board members should meet with the board chair for an overview of the organization.

- Prospective board members should receive relevant program materials.

- Provide names of several board members whom the prospective new member might contact with questions.

- Identify if there are any conflicts of interest with the candidate.

- Invite the prospective new member to a board meeting. [8]

At the University of Hartford we have done our best to attract board members from different areas of the construction industry. Practitioners in the construction industry bring a wealth of knowledge, ability, and resources to the committee.[9] This included architects, engineers, construction managers, landscape architects, interior designers, and attorneys. However, we quickly realized we were missing academics, and we are now searching for board members with an academic background to complement our existing board. Getting people from other facets of the construction industry has allowed us to connect with different parts of our industry and come up with several ideas that a more narrowly focused board would not have seen.

\section{WhAT SHOULD ThEY KNOW BEFORE JOINING?}

Serving as a board member is one of the most challenging and rewarding of volunteer assignments. While appointment or election to a board is an honor, board members have

\section{8-1-4244-1970-8/08/\$25.00 @2008 IEEE} $38^{\text {th }}$ ASEE/IEEE Frontiers in Education Conference responsibilities that require a commitment of time, skill, and resources. Prospective board members do themselves a service and show that they are serious about the commitments they make by asking some basic questions before joining an organization's board. Long-time board members might also benefit from a review session that answers the following questions:

- What is the organization's mission?

- Can I visit the university to observe the program firsthand?

- Does the program have a strategic plan that is reviewed on a regular basis?

- How is the board structured?

- Are there descriptions of the board committee functions and responsibilities?

- How are committee assignments made?

- Who are the other board members and what is their background?

- What are the ways that a board member can contribute to the board and the program?

- How much time will be required for meetings and special events?

- What is the board's role in fundraising?

- How do board members and university faculty typically work with each other? [10]

Selected background information can also provide a useful overview of the university, goals of the board, and the responsibilities of the board members. Helpful materials for prospective members include:

- The university's and program's annual reports.

- The university's most recent financial statement.

- A list of the current board members, titles, and all affiliations.

- A description of board members' responsibilities.

- A board organizational chart.

- The university's and program's organizational chart.

- The university's and program's newsletters, brochures, and other publications.

- Newspaper or magazine articles about the university and program.

- A brief biography of the board and program chairs [11].

In retrospect, we could have improved the preparation of our board members by giving them more information about the University of Hartford and the College of Engineering, Technology, and Architecture, as opposed to only the Department of Architecture program. This would have provided a better understanding of how our program fits in the university and college setting. In the future, our new board members will be better prepared for their role and by completing an orientation process to ensure they are all operating from the same "script". We would hope that

October 22 - 25, 2008, Saratoga Springs, NY F3A-11 


\section{Session F3A}

orientation could also be a strong team-building activity. This may have to be conducted as often as once a year and/or whenever new members have been recruited.

\section{What ABOUT INCLUSIVITY AND DIVERSITY?}

A university organization such as an advisory board should respect all people's race, religion, ethnicity, gender, age, social status, sexual orientation and ability. The board should:

- Reflect the diversity of your organization and the broader community.

- Conduct its business in facilities that are accessible to persons of all ability levels.

- Act in a way that furthers opportunities among individuals and the community.

- Act in ways that are consistent with the mission of the program and university. [12]

At the University of Hartford's Department of Architecture we have made the effort needed to have a successful mix of people from diverse backgrounds.

\section{How Do You Generate Member Participation?}

To increase attendance and/or participation in board and committee meetings, consider some or all of the following:

- Ensure board chair's understanding and ability to convey the role of the board to the board members.

- Ensure adequate orientation that describes the program and its uniqueness.

- Have ground rules that support attendance and participation.

- Develop a board member attendance policy.

- Quietly let go of deadwood.

- Consider using subcommittees to increase individual responsibilities and focus.

- Have a staff member participate with the board to help with administrative support and providing information.

- Generate minutes for each board meeting to get closure.

- Consider having low-attendance members involved in some other capacity of service to the program.

- Rotate in new members each year. [13]

Our board has had some attendance issues. However, this is improving with some reorganization and the creation of a greater sense of obligation to our program. In the future, if a board attendance problem exists regarding a member, the board chair will promptly contact the member to discuss the problem and at a subsequent meeting the board will decide what action to take regarding future membership on the board. If it is necessary, membership would be quietly terminated and a search would immediately begin to recruit a new board member.

\section{CONCLUSION}

Regardless of who is on your advisory board, it is important that you can rely on them for good advice. Very simply put, an advisory board, or advisory committee, is a collection of individuals who bring a connection to industry, as well as unique knowledge and skill needed to complement the knowledge and skill of the program's leadership and faculty. Board leadership requires, above all, that the board provide a clear direction. To do so, the board must first have a sense of group responsibility and an adequate understanding of its own job. The board's most important job is to develop a mission and mission-related statement that clearly describes what the desired result will be.

At the foundation of this paper is a strong conviction that an advisory board will enhance the collaboration between higher education and the industry it serves and have a direct and positive impact on the educational process and the success of the school or program. We have benefited from teaming with industry to guide our programs. At the University of Hartford the Department of Architecture is in the College of Engineering, Technology, and Architecture. On the undergraduate level we have an Architectural Engineering Technology program and on the graduate level we have a Master of Architecture program. These are both developing programs, both in need of a better connection to industry, and it is through our newly formed advisory board that we are doing so. Our advisory board has played a key role in our program's success, and the right mix of personalities and experience has helped keep us focused and on track to meet our goals.

\section{REFERENCES}

[1] Geehan Advisory Boards, "Advisory Board Facts", http://www.geehanadvisoryboards.com/advisory.html (retrieved March 7, 2005).

[2] Geehan Advisory Boards, ibid.

[3] Free Complete Toolkit for Boards, "Overview of Board Roles and Responsibilities", http://www.mapnp.org/library/ boards/boards.htm (retrieved April 25, 2005).

[4] Free Complete Toolkit for Boards, ibid.

[5] Bostwick, W. and Buchanan, W., "Where You Lead Your Advisory Committee Is Sure to Follow", Proceedings 2000 Conference for Industry and Education Collaboration, pp. 145, 2000.

[6] SBA Online Women's Business Center, "Responsibilities of a Board Member", http://www.onlinewbc.gov/Docs/ manage/bod_responsibility.html (retrieved April 25, 2005)

[7] SBA Online Women's Business Center, "What Makes A Successful Board Member", http://www.onlinewbc.gov/Docs/ manage/successful_bod.html (retrieved April 25, 2005)

[8] Recruiting New Members of Boards of Directors, "Guidelines for Recruiting New Board Members", http://www.mapnp. org/library/boards/recruit.htm (retrieved April 25, 2005).

[9] O’Dea, M., "Industrial Advisory Committees: An Opportunity For Renewing the Partnership in Construction Education", Proceedings 
2000 Conference for Industry and Education Collaboration, pp. 142, 2000.

[10] BoardSource Building Effective Nonprofit Boards, "What should I know before joining the board?", http://www.board source.org/FullAnswer.asp?ID=95 (retrieved April 25, 2005).

[11] BoardSource Build Effective Nonprofit Boards, ibid.

[12] Board Development, "To Establish an Organizational Vision and Mission", http://www.boarddevelopment.org/display document.cfm?docment_id36 (retrieved April 25, 2005).

[13] Board Guidebook, "Ideas to Generate Participation in Committees", http://www.mapnp.org/library/boards/goodcmte.htm (retrieved April $25,2005)$.

\section{AUTHOR INFORMATION}

Daniel Davis, AIA is a Professor in the University of Hartford's College of Engineering, Technology, and Architecture in the Department of Architecture. He also has years of experience as a Design Architect and is the Director of Design for the Hartford, CT office of Fletcher-Thompson, Architects and Engineers. Davis holds baccalaureate degrees from Catholic University and Pratt Institute and a second professional degree Master of Architecture from Pratt Institute. 